therefore there is very close parallelism between tille: production and leaf dry weight.

Height and stem dry-weight data have also been graphically presented for the eight flowering classes and show quite distinctive features as compared to tiller number and leaf dry weight. 'Actual' stems have been dissected out from each tiller of a sample and weighed exclusive of leaf sheaths, which have been considered as parts of leaves. It appears that differences in final heights of varieties belonging to different flowering classes are not so great as exhibited by tiller number or leaf dry weight. The same is true for stem dry weight. Stem elongation appears to be determined by the developmental process and is correlated with spike growth. When periodic data for height are considered, it is found that stem growth starts earlier in early varieties, and the period for which the curves remain flat increases progressively with the lateness of flowering in a variety. Flatness of curves is very much in evidence in the case of stem dry weights. Apparently no stem growth takes place as long as the growing point in wheat remains in a vegetative condition. Stem growth is initiated after the growing point has changed from the vegetative state to the reproductive state. In the case of height data the slight upward trend of the flat portions of different curves is due to the elongation of leaf sheaths and not due to stem growth. Actual elonga. tion of intermodes in varieties of the earliest flowering class $(A)$ begins 40 days after sowing, and it is progressively delayed with lateness in flowering. Thus stem growth is initiated 120 days after sowing in very late varieties of the class $H$. It is, however, worthy of note that the growth-rate of 'actual' stem is more dependent upon temperature and other environmental factors rather than on the time of flowering. This becomes evident from the steeper slopes of curves for flowering classes $G$ and $H$. In the case of these two flowering classes it is most probably due to the relatively high temperatures in the later part of the season, when stem growth takes place, that the rate is higher.

So far as I am aware, this is the first time that growth analysis of a very large number of genotypes of wheat, differing widely in their time of flowering and growth pattern, has been attempted and correlations established. The mass of data which has been collected is being analysed and will be dealt with fully in subsequent communications elsewhere. However, it will not be out of place to mention here that these correlations have been further confirmed by giving photoperiodic and vernalization treatments to a number of wheat varieties belonging to different flowering classes. A study of these correlations is likely to throw some new light on the problem of inheritance of growth and development.

Botany Department,

\section{J. J. Сhinoy}

University of Delhi,

Delhi.

April 10.

${ }^{1}$ Whyte, R. O., Biol. Rev., 14, 51 (1939).

'Gregory, F. G., "Sixth International Bot. Congress", 2, 18 (1935).

' Purvis, O. N., Ann. Bot., 48, 919 (1934).

4 Purvis, O. N., and Gregory, F. G., Ann. Bot., N.S., 1, 569 (1937)

' Kuleshov, N. N., J. Amer. Soc. Agron., 25, 688 (1933).

- Whyte, R. O., Herb. Abst. (No. 4 suppl.), 52 (1942).

${ }^{7}$ Chinoy, J. J., Curr. Sci., 11, 400 (1942).

${ }^{8}$ Chinoy, J. J., Indian Farming, 8, 72 (1947).

- Dastur, R. H., and Chinoy, J. J., Indian J. Agri. Sei., 2, 431 (1932).

${ }^{10}$ Chinoy, J. J., Nature, 159, 442 (1947).

\section{Lime Disease in the Gold Coast}

A DISEASE of seedling lime trees in the Cape Coast district, Gold Coast Colony, is threatening to destroy the industry. Research has revealed the cause of the malady to be a virus existing in at least two strains. In the first of these, symptoms include a one-sided death of the tree coupled with veinal fleckings on the young leaves and severe pitting of the trunks and branches. In the other, conspicuous dwarfing together with the usual veinal symptoms and subsequent death occur. Most sweet citrus and rough lemon appear to be symptomless carriers of the virus.

It has been found, however, that limes budded on rough lemon do well where seedling limes die, and rehabilitation of the industry is proceeding along these lines, together with a search for resistant trees.

Vector experiments made with Aphis Taveresi (Del Guercio) after the work of Meneghini ${ }^{1}$ with Tristesa indicated that this is the vector. The aphids were collected from rough lemon seedlings in the field and fed on lime seedlings experimentally infested with the virus disease for periods varying from five minutes to twenty-four hours. In one experiment, test plants enclosed in cages ${ }^{2}$ and 'bombarded' with these aphids developed leaf symptoms, whereas controls kept free of insects remained free of such symptoms, and further experiments are in hand to confirm this result.

Thanks are expressed to the director and staff of the West African Cacao Research Institute, Tafo, for help and advice on the insect work.

Department of Agriculture,

\section{W. A. Hughes}

C. A. Lister

Accra.

June 23.

${ }^{1}$ Meneghini, M. Biol. Abs., 21, 8, 20758 (1947).

${ }^{2}$ Hamilton, Marion A., Ann. App. Biol., 37, 487 (1930).

\section{Ecidia of Barley Dwarf Rust}

IN April 1948, Dr. R. W. G. Dennis wrote to me announcing the discovery at Inwood Copse, near Ham Spray, and growing naturally, of an æcidial stage on Ornithogalum pyrenaicum L., which he proved to belong to Puccinia hordei Otth. $(=P$. anomala Rost. $)^{1}$. This was of great interest to me, not only because it was the first record of the rcidial stage of this rust in England, where I carried out, in 1934 and 1937, a detailed survey in search of it in the fields around Cambridge, but also because although this species has been named as a host for the gameto. phytic stage of this rust ${ }^{2}$. I was unable to infect it during exhaustive attempts carried out years ago in Portugal ${ }^{3}$.

Two hypotheses were then possible: $(a)$ that the æcidia found in England belonged to a physiological race of Puccinia hordei different from those tested before; or $(b)$ the plants of Ornithogalum pyrenaicum, where the spermogonia and æcidia had been found, belonged to a different strain congenial to this rust. In order to examine these two hypotheses, material was obtained through the kindness of Dr. Dennis, a uredosporic culture established from the original æcidia and maintained by Prof. F. T. Brooks; later on, Dr. Dennis sent also some bulbs of $O$. pyrenaicum 